\title{
A situação actual do Sida ao nível mundial
}

Alfredo Cravador *

O objectivo deste artigo é informar sobre a situação actual do SIDA nos seus aspectos e implicaçð̃es mais variados, da sua evolução desde que foi descoberto e dos problemas sociais, políticos, legislativos e morais que o seu reconhecimento e a estratégia para o eliminar têm levantado em diferentes países.

Ele procura igualmente divulgar duma maneira necessariamente simples, mas ao alcance da maioria, o que se conhece actualmente sobre o vírus responsável da doença, sobre as vias que levam à aquisição da infecção viral e que veiculam a sua propagação assim como sobre os meios profiláticos e terapêuticos actualmente disponiveis e dos que se preparam para o futuro.

\section{Introdução histórica}

Apesar de o reconhecimento do SIDA como doença distinta ter coincidido temporalmente nos Estados Unidos, no Haiti e em África é provável que a infecção tenha começado muito antes em África. Esta hipótese é apoiada por estudos efectuados com base em análises retrospectivas (de validade contestada) de bancos de soro recolhido no Zaire e nas Áfricas Ocidental e Oriental nos anos 60 e 70 e na frequência, anormalmente crescente, de doença, que se sabe hoje serem uma consequência directa do Sindroma de Imunodeficiência Adquirida (SIDA), em períodos que variam com a localização geográfica e com os sintomas, e cuja ocorrência é manifesta já nos fins dos anos 70 na África Central.

O SIDA foi reconhecido como uma condição patologica distinta há apenas 6 anos. Houve desde o início provas concretas de que a doença era causada por um agente infeccioso. A prova de que um agente infeccioso é um vírus baseia-se na demonstração de que o suposto agente é antigeneticamente distinto (isto é desencadeia uma resposta imunitária do organismo produzindo anticorpos particulares dirigidos contra este novo agente patogénico), de que pode ser cultivado em células de um hospedeiro susceptível e de que é capaz de se transmitir de uma célula infectada para outra. A prova de que o vírus pode infectar animais susceptíveis sãos, causa problemas quando a infecção é quase sempre fatal, mas foi feita com o sacrifício de um grande número de chimpanzés.

O que é absolutamente admirável e ao mesmo tempo uma prova da capacidade actual da ciência laboratorial é que o reconhecimento do SIDA como uma doença distinta e nova tenha sido realizado em apenas dois anos. Mais prodigioso é ainda que os genomas inteiros de 4 subtipos distintos do vírus IIIV-1 (IHuman Immuno Virus) e uma do IHIV-2 responsáveis do SIDA tenham sido identificados e caracterizados pela sequência dos nucleótidos (motivos moleculares) que interligados formam os ácidos nucleicos (macromoléculas biologicas que constituem os genes). Mas apesar da rapidez com que novos dados científicos sobre o IIIV são descobertos e publicados pouco se sabe com precisão sobre a história natural do SIDA. A falta de recuo de que dispomos em relação à doença impede o conhecimento correcto e completo do seu aspecto epidemiologico.

Uma hipótese baseada na comparação das estruturas nucleotídicas do HIV-1 e do IIIV-2, vírus com incidências regionais distintas em África (o IIIV-1 foi já identificado na África Central assim como na América do Norte e na Europa e o IIIV-2 mais recentemente na África Ocidental e em particular na Guiné Bissau e em Cabo Verde) sugere que eles derivam de um antepassado comum com propriedades e potencial patogénico semelhantes. Este antepassado comum teria existido há muito tempo numa população humana e evoluído para as formas actuais, resultando o surto simultâneo da epidemia na África Central e Ocidental da modificação dos parâmetros epidemológicos nestas regið̋es, tais como a urbanização descontrolada, originando a infecção de populaçð̃es mais vastas. A razão pela qual o vírus só recentemente foi detectado pode ser devida ao facto do caracter patogénico deste tipo de vírus não poder ser posto em evidência antes de se ter propagado numa proporção significativa da população. Numa África com pobres recursos sanitários e médicos, onde outras infecçōes tais como a malária representam causas primárias de morte, pode-se compreender que casos isolados de SIDA tenham passado despercebidos. O tempo de incubação podendo ser bastante longo implica que um número considerável de portadores sãos do vírus o pode continuar a transmitir durante anos. Este período de incubação, ou seja o intervalo de tempo entre o desencadeamento da infecção e o aparecimento dos sintomas da doença era até há pouco considerado 4 ou 5 anos porque não houve mais do que este tempo para que as consequências da infecção se manifestassem. Dentro de 5 anos à luz da evidência nessa altura disponível poder-se-á dizer que o período de incubação é talvez de 9 ou 10 anos. O que implica que as pessoas infectadas terão o dobro do tempo para passar a infecção a outros. As últimas análises estatísticas são mais pessimistas prevendo um tempo de incubação médio de 15 anos.

\section{A propagação do vírus do SIDA}

É um facto bem estabelecido que os linfocitos T (células presentes no sangue especializadas, a par dos linfó-

* Laboratoire de Génétique Appliquée, Departement de Biologie Moléculaire, Université Libre de Bruxelles. 
citos B, na defesa imunitária do organismo) são as células hospedeiras alvo do ataque infeccioso do vírus (daí a denominação de vírus de imunodeficiência humana - em inglês Human Immunodeficience Virus HIV). Os linfocitos T são abundantes no sangue e encontram-se igualmente no esperma. Os meios priveligiados de propagação são necessariamente todos os que implicam uma troca de sangue ou relaçðes sexuais entre um indivíduo infectado e um são. Nenhum outro meio de propagação foi até hoje posto em evidência. Pertencem pois a grupos de risco em sociedades desenvolvidas, os indivíduos sujeitos a transfusø̋es sanguíneas frequentes, tais como os hemofilicos, os indivíduos praticando a promiscuidade sexual (tais como homosexuais mas não necessariamente), os consumidores de drogas intrevenosas e as pessoas que praticam a prostituição.

O desfecho tem sido sempre fatal. Os indivíduos infectados ficam imunodeficientes devido à destruição das suas células $\mathrm{T}$ tornando-se extremamente frágeis a qualquer agente patogénico e sofrem frequentemente de problemas gastroinstestinais, de diarreia severa, de perda de peso, de infecçðes tais como pneumonia, dé tuberculose de toxoplasmose ou de cancro, sendo frequente o sarcoma de Kaposi generalizado. A penetração do vírus no cérebro também foi demonstrada, originando a perda das faculdades mentais e a demência. No entanto não se conhece qual a probabilidade de uma pessoa infectada poder passar a infecção a outra como consequência de um simples acto sexual. $\mathrm{O}$ melhor que se pode fazer é calcular o produto daquela probabilidade com uma função aritmética que é essencialmente uma medida da contribuiçâo da promiscuidade à transmissão do virus. A conclusão é simples: indivíduos promíscuos têm uma influência na propagação da epidemia que é proporcional ao quadrado do número dos seus parceiros sexuais.

\section{O SIDA na África}

Um melhor conhecimento e compreensão da ocorrência do SIDA na África ajudaria a estabelecer parâmetros essenciais tais como a duração da capacidade transmissora da infecção dos portadores do vírus, a sua distribuição temporal (episódica ou outra) e a probabilidade de transmissão por encontro heterosexual decorrente de diversos géneros de encontros. Não é tarefa fácil devido à dificuldade até há pouco manifestada pelos governos africanos em admitirem que estão confrontados com um problema epidemiologico de dimensðes colossais. São igualmente fracas as probabilidades de que dados epidemiologicos úteis possam ser reunidos no I Iaiti que se supøe ter sido desde há alguns anos o ponto de ligação entre a África e os Estados Unidos da América.

A África é um exemplo e um campo priveligiado da persistência e desenvolvimento da epidemia. As características da incidência da doença particulares a este continente diferenciam-no tanto qualitativamente como quantitativamente dos outros focos de propagação. De facto os casos de SIDA estão igualmente distribuídos entre homens e mulheres. A propagação é heterosexual e não existe actualmente evidência de transmissão homosexual ou por via de administração de drogas intravenosas, factores socio-culturais com fraca implantação no Continente Africano. A informação disponível sobre a incidência actual do SIDA neste continente tem pecado pela falta de precisão decorrente por um lado das limitaçðes das infraestruturas médicas e hospitalares e por outro lado pela dificuldade de diagnosticar a doença devido à falta de meios laboratoriais sofisticados que permitam fazer a distinção nítida com outras causas de imunodeficiência própria a paises em vias de desenvolvimento. No entanto um quadro descritivo da epidemologia está a ganhar corpo graças a uma atitude mais favorável dos governos africanos em colaboração com investigadores internacionais. A conclusão é de que a África Central, e em menor escala as Áfricas Ocidental, Oriental e Meridional, estão severamente atingidas pela epidemia; entre 1 e $18 \%$ de dadores de sangue sãos e entre 27 e $88 \%$ de prostitutas estão infectados, dependendo as variaçðes do estatuto socioeconómico e la localização geográfica. A incidência anual da infecção nas Áfricas Central e Oriental é actualmente de $0,75 \%$ da população geral.

\section{Os governos dos países desenvolvidos confrontados com uma epidemia de caracteristicas novas}

O reconhecimento por parte de um governo da existência duma epidemia no seu território implica uma tomada de decisðes que visem combater, deter e eliminar a propagação duma doença cuja evolução pode vir a atingir proporçð̃es catastróficas. O caso do SIDA tem várias particularidades que têm constituido outras tantas dificuldades referentes primeiramente ao reconhecimento oficial da doença e em seguida à adopção de medidas eficazes e aplicadas com discernimento. As implicaçð̃es são políticas, sociais, legislativas, económicas e morais.

O SIDA é uma doença nova de características epidemologicas ainda imperfeitamente conhecidas e de desfecho fatal. A medicina está desarmada para a combater. O primeiro alvo no mundo desenvolvido foram os meios considerados marginais pela sociedade tais como homosexuais, drogados e prostitutas. Um outro grupo de risco é o dos homofílicos cuja infecção provém de sangue contaminado que lhes foi transmitido em centros hospitalares e de cuja enfermidade e morte são responsáveis em última análise as autoridades governamentais responsáveis pela saúde.

Se bem que exista actualmente um teste de diagnostico que permite detectar que o sangue de um dador é seropositivo (esteve em contacto com o vírus), a sua segurança não é total, uma das razð̄es sendo a ausência de anticorpos - que é o que o teste detecta - durante um período que pode ultrapassar nove meses a partir do momento em que a infecção começou, lapso de tempo durante o qual um indivíduo pode propagar o vírus com completo desconhecimento de causa.

A tentação é grande para recorrer a medidas drásticas que tornem obrigatório um teste de diagnóstico da infecção para certos grupos sociais ou estrangeiros e o registo dos individuos infectados ou que tendam a seguir a pista da infecção. É uma reacção que exprime o pânico face a um inimigo contra o qual não se dispð̄e de arma apropriada e a necessidade de tranquilizar, seja a que preço fôr, a população. A eficácia de tais medidas é duvidosa dada a imperfeição dos testes para além de que legislar sobre tal matéria é arriscar-se a entrar em conflito com a declaração dos.direitos do homem. Estigmatizar a doença, submeter ao ostracismo os portadores do vírus é recuar aos tempos tenebrosos das colonias de leprosos.

O carácter de transmissibilidade por via sexual levanta obstáculos de ordem moral visto que só uma lingua- 
gem isenta de tabus e necessariamente explicita para ser eficaz, no âmbito de uma ampla campanha de informação e de educação, pode constituir uma arma adequada no combate à propagação da epidemia.

Serão necessariamente elevados os custos inerentes a uma campanha de esclarecimento e de educação eficiente à escala de um país inteiro, à criação da infra-estrutura apropriada para aplicar uma profilaxia necessária para conter o alastramento da doença e para dar assistência e tratamento aos pacientes atingidos de SIDA.

Eles serão tanto mais elevados quanto mais tarde o combate for desencadeado contra um inimigo que, parecendo ausente porque bem camuflado, so se manifesta depois de ter produzido uma devastação que anos de ignorância ou de inércia deixaram propagar.

A primeira reacção dos governos incluindo o dos Estados Unidos da América, o país industrializado de longe o mais atingido, e na peugada do qual seguem os paises europeus ocidentais desenvolvidos com 1 ou 2 anos de atraso, foi a de dar pouca atenção a uma doença própria aos meios marginais e pouco digna de interesse. Esta tendência foi magnificamente ilustrada na peça dramática do jornalista Larry Kramer, que no começo dos anos 80 compreendeu o perigo que representava o aparecimento do SIDA em Nova Iorque nos meios homosexuais e se debateu contra a inércia dos governantes numa tentativa infrutífera para alertar as autoridades e a imprensa. Ele denunciou a indiferença, a ausência de regras morais e pessoais e combateu a propensão para o isolamento em guetos. Larry Kramer morreu entretanto de SIDA e os Estados Unidos contam hoje, segundo as estimativas mais recentes, com cerca de 3 milhøes de pessoas infectadas.

$\mathrm{Na}$ República Federal da Alemanha o SIDA foi ignorado por muito tempo. O comité de Saúde do Parlamento foi pela primeira vez incumbido do problema do SIDA no Outono de 1985 . A primeira sessão plenária realizada um ano mais tarde durou meia hora. $\mathrm{O}$ único resultado foi uma resolução no sentido de informar o público e de incentivar a investigação. O Ministro da Saúde Heiner Geissler não fez praticamente nada para combater o SIDA durante a sua passagem pelo governo, considerando a doença como um problema próprio a grupos de risco. A sua sucessora Rita Sussmuth, de opinião diferente, começou uma campanha de esclarecimento dispendendo milhōes de marcos em publicidade em revistas, jornais, televisão e folhetos. Avaliou-se em 100000 o número de pessoas actualmente infectadas na RFA que serão 500000 em 1990.

No Japão os médicos têm sido relutantes em declarar os doentes ao Ministério da Saúde devido ao risco de ostracismo a que estes serão votados pela sociedade e em particular pelas escolas. Pacientes com o SIDA não têm sido declarados como não têm sido as vias de propagação da infecção. A primeira mulher a ter sido oficialmente reconhecida como tendo morrido de SIDA no início de 1987 foi uma prostituta de Kobe depois de ter sido transferida de hospital em hospital para ser tratada de outras supostas doenças. A ignorância geral sobre a doença provocou uma vaga de surpresa e originou uma corrida aos testes de diagnóstico principalmente pela parte dos homens que frequentaram saløes de massagens e outras prostitutas da região. Suspeita-se actualmente que milhares de homosexuais estão infectados assim como 30 a $40 \%$ dos 5000 hemofílicos contaminados pela importação dos Estados Unidos da América de sangue com o vírus.
Na URSS, depois de vários anos de denuncia do SIDA como sendo uma doença própria ao capitalismo decadente ou de atribuir ocasionalmente a sua origem a experiências da guerra bacteriológica executadas pelos E.U.A., os médicos soviéticos começaram a publicar entrevistas com funcionários superiores responsáveis pela saúde pública sobre os meios de evitar a contaminação. As medidas imediatas incluem a possibilidade de as pessoas se submeterem anonimamente a exames de sangue numa clínica de Moscovo. Aparentemente as autoridades decidiram não impôr sançōes legais contra os que procuram assistência sofrendo de SIDA (um acto homosexual está sujeito a uma sentença que pode ir até 5 anos de prisão).

\section{As medidas de combate adoptadas em diferentes países}

A luta contra o SIDA está a desenvolver-se em várias frentes. Para além das verbas gigantescas que estão a ser atribuídas à investigação (sobretudo nos Estados Unidos da América, na Grã-Bretanha e na França) e que visam sobretudo a preparação de uma vacina e o desenvolvimento de medicamentos eficazes, meios consideráveis estão a ser utilizados em campanhas de informação e de educação das populaçōes e na generalização dos testes de diagnósticos no sentido de travar a propagação da epidemia.

A administração americana requisitou 1 milhão de dólares para o orçamento de investigação e de prevenção de 1988 e Sheldon Wolff co-presidente da Academia Nacional da Ciência reclama mais 1 milhão de dólares anualmente até 1991 a fim de assegurar um projecto eficaz no ramo da saúde pública e da educação. O Serviço Público de Saúde (Public Health Service-PIIS) tem um projecto que visa prevenir e controlar o alastramento do SIDA graças a um plano radical de educação que inclui crianças abaixo de 8 anos.

Medidas que tocam forçosamente aspectos sexuais suscitam inevitavelmente objecçōes laivadas de puritanismo e abrem o debate no plano do moralismo social. É assim que membros do Gobinete do Secretário da Educação William Benett criticam o plano pelo seu lado "imoral", ultrajados pela perspectiva de que crianças de 8 ou 9 anos possam ter conhecimento na escola da existência de relaçőes sexuais anais. Um memorando de Jack Klenk do Departamento da Educação a Gary Noble coordenador da luta contra o SIDA do PIIS pede a inclusão com urgência no programa, de um apelo para que se evite a promiscuidade sexual e as prostitutas, duas mensagens consideradas básicas, e reclama uma participação dos pais na educação sobre o SIDA. Pede ainda que o programa especifique que as crianças não devem ter relaçðes sexuais e que o comportamento sexual dos adultos deve ser baseado na fidelidade, no comprometimento e na maturidade. O programa deve igualmente fazer a distinção entre o relacionamento heterossexual e homossexual, salientando que a heterossexualidade dentro do casamento é considerada pela maioria dos americanos como a normalidade da sexualidade humana.

A sugestão do PIS sobre a protecção assegurada pelo uso de preservativos é posta em questão. Klenk sugere que se alarmem as pessoas no sentido de evitarem um parceiro sexual infectado.

Também o Dr. Valentin Pokrovski do Instituto Central de Epidemologia da U.R.S.S. aconselha um modo de vida sóbrio em todas as suas manifestaçð̄es e uma vida sexual ordenada. 
No campo legislativo as tendências que se salientaram na Conferência de Atlanta patrocinada pelo Center of Disease and Control (Centro de Doença e de Contolo) realizado em Março último e na qual estiveram presentes responsáveis pela Saúde Pública, advogados das liberdades cívicas e representantes de grupos de risco, apontam para a necessidade de se oferecerem testes de diagnósticos de maneira mais agressiva a indivíduos pertencentes a grupos de risco a realizar em centros de tratamento de doenças transmitidas sexualmente e de assistência a consumidores de drogas intravenosas. Os exames não devem ser obrigatorios. Reclama-se uma confidencialidade sobre os resultados dos testes. Todos os dados que permitam a identificação dos pacientes, excepto idade e sexo, deverão ser destruídos antes que os exames sejam efectuados.

Uma campanha iniciada recentemente pelo governo da Grã-Bretanha utiliza a palavra de ordem: "Não morra na ignorância", que ilustra a pressão política crescente exercida sobre o governo pelo corpo médico, cada vez mais preocupado com a ignorância generalizada sobre - SIDA e com a frustação resultante da incapacidade de se lhe opor eficazmente.

O objectivo principal desta campanha educacional é deter a propagação do vírus a curto prazo e para isso se aconselha às pessoas um comportamento que reduza ao mínimo as probabilidades de contrair a infecção. A British Medical Association recomenda às pessoas que tiveram mais de um parceiro sexual durante os últimos 4 anos que se abstenham de dar sangue - acto voluntário não remunerado na G.B. Esta iniciativa causou muita confusão e provocou bastante hostilidade, sobretudo da parte dos organismos que estão a tentar angariar recursos para constituir um banco nacional de sangue.

O combate à ignorância faz igualmente parte de uma luta contra os mitos que originam medidas despropositadas e injustas. É neste sentido que se tem alertado as autoridades escolares e os professores insistindo para não se preocuparem em manipular objectos tocados por pessoas infectadas assegurando que não existem razð̋es válidas para se desinfectarem retretes, loiça ou talheres. Não há conhecimento de casos de infecção transmitida em escolas nos E.U.A. ou na G.B., não podendo o virus ser propagado através do contacto pessoal ocasional.

$\mathrm{Na}$ G.B. onde as últimas avaliaçð̄es sugerem a existência de cerca de 110000 infectados em 1985, uma verba de 20 milhões de libras está a ser aplicada na campanha anti-SIDA nos meios de comunicação, em cartazes e folhetos que têm sido distribuídos oficialmente a nível nacional e nos quais se aconselha 0 uso de preservativos. Tem no entanto havido severas restriçōes aos anúncios públicos. Apesar de tudo, as convençōes têm sido derrubadas e a palavra preservativos, anteriormente excluída do vocabulário da sociedade educada, é agora utilizada em emissðes de TV pública e comercial nas quais se ensina a utilizar este objecto tão desdenhado.

Para além das verbas destinadas à campanha de esclarecimento e de educação, cerca de 15 milhôes de libras serão atribuídas ao Medical Research Council para a realização de programas de investigação na área das vacinas e dos medicamentos.

Em França onde a incidência da epidemia é comparável à da G.B., a Ministra da Saúde Michèle Barzach optou sem ambiguidades por uma política de incitação ao uso de preservativos e de venda em farmácias de se- ringas descartáveis. Uma verba equivalente a 2 milhðes de dólares vai ser consagrada a uma campanha publicitária na televisão a começar no Verão. Somas importantes estão a ser investidas na compra de novos equipamentos e em projectos exigindo a abertura de novos postos para a investigação sobre o SIDA.

"O Carnaval acaba na 4. ${ }^{\text {- }}$-feira de cinzas, o SIDA não" é o título de um cartaz afixado num centro de juventude alemã de Berlim. A Ministra da Saúde da Democracia Cristã alemã, Rita Sussmuth indigitada em Setembro de 1986 começou a campanha de anúncios, publicidade em jornais, revistas, televisão, folhetos e cartazes no sentido de um amplo combate de esclarecimento e de educação da população para o qual entra com uma verba de 20 milhðes de marcos. Rita Sussmuth que é uma fervente proponente da utilização dos preservativos foi ao ponto de se fazer fotografar para a popular revista Der Spiegel com um enorme preservativo enfiado na cabeça. Em Berlim houve uma redução significativa do número de casos registados de SIDA como consequência da campanha.

O governo é obrigado ao mesmo tempo a combater certas tendências democratas cristâs opositoras da sua campanha de saúde que é apoiada pelos liberais, pelos sociais-democratas e pelos ecologistas. Durante esta contra campanha o perito de saúde do CSU Kurt Faltlhauser escreveu um artigo dirigido aos deputados do CSU do Parlamento em Bona pedindo que seja instaurado um teste de diagnóstico obrigatório para grupos de risco tais como hemofílicos, toxicómanos e prostitutas registadas como tal, assim como mulheres grávidas, viajantes e estrangeiros provenientes de paises em risco. Um teste anónimo gratuito deveria igualmente ser oferecido a todo o residente da RFA. Para mais tarde, o CSU recomenda o teste compulsorio e o registo para toda a população. O Ministro do Interior do CSU Friedrich Zimmermann considera até necessário que sejam impostas restriçðes a pessoas infectadas. Erich Riodl deputado do CSU propōe separação por grupos em locais tais como escolas, clubes, fábricas, etc.

Dando um passo legislativo neste sentido o governo regional da Bavária decidiu tornar obrigatório o teste anti-SIDA para todos os suspeitos. Os que se recusaram, a tal serão obrigados. A prostituição feminina e masculina pertencem a esta categoria, assim como qualquer pessoa vista a falar com eles. Toxicómanos, presos e até candidatos a postos em empresas públicas terão o seu sangue examinado. Os candidatos seropositivos serão rejeitados. Estas medidas extremistas foram criticadas por outros Estados assim como pela Ministra da Saúde que declarou ser este um meio errado de combater a epidemia, dificilmente aceitável e ineficaz. IHá cerca de um mês numa conferência dos Ministros da Saúde dos 11 Estados da RFA foram rejeitadas as propostas do governo da Bavária para o registo obrigatório dos portadores do vírus. É pois pouco provável que este Estado consiga impôr as suas propostas extremistas à lei Federal. O governo da Bavária planeia contudo levar por diante o seu projecto. Estes planos levaram já a uma migração em massa das pessoas infectadas com o vírus do SIDA para o Estado vizinho de Baden-Würtbemberg e Hesse. Um relatório indica que $20 \%$ das pessoas procurando tratamento e conseIho em Ulm, cidade junto à fronteira com a Bavária, provém deste Estado.

Em Munique, testes voluntários vão estar à disposição de mulheres grávidas. Um programa piloto começou a funcionar nos hospitais universitários. 
Os países do leste europeu que estão mais avançados na luta informativa contra a epidemia são a República Democrática Alemã com um serviço de informação bem desenvolvido sobre o SIDA e programas para discutir os riscos dos homossexuais e dos heterossexuais possuindo vários parceiros, e a Polónia bem explícita na sua campanha informativa com a televisão mostrando dois homens na cama, um deles retirando um preservativo dum pacote.

Na URSS, com 2800 casos oficialmente reconhecidos, uma campanha de massa incluindo publicaçðes especiais sobre o SIDA está planeada, e existe já um serviço informativo por telefone. O Ministério da Saúde vai estabelecer uma rede de laboratórios de diagnóstico que examinará o sangue de todos os dadores assim como de todos os pacientes apresentando sintomas indicativos de SIDA. Está planeado um projecto de treinamento a grande escala para especialistas em diagnóstico e tratamento; uma nova clínica especializada será aberta, e 40 institutos trabalhando sobre esta doença receberão aumentos de verbas.

Depois da morte de SIDA de uma prostituta de Kobe e do relato na imprensa sobre uma mulher de Kochi que ignorou o conselho do médico e engravidou sem avisar o marido de que era portadora do vírus do SIDA, insistindo em dar à luz mesmo sabendo que os riscos de que a criança seja infectada são extremamente elevados, o Japão prepara-se para introduzir uma legislação reconhecendo o SIDA como doença cuja declaração é obrigatória. Este projecto tem originado protestos da parte dos que consideram que a lei será um atentado grave aos direitos humanos.

Prevêem-se as disposiçð̄es seguintes: os médicos terão um prazo de 7 dias para notificar a idade, o sexo e a fonte da infecção dos portadores do vírus aos governos das prefeituras. Se um médico achar que um paciente desacata as suas instruçð̌es, deverá imediatamente comunicar o seu nome e endereço às autoridades da perfeitura. Estas serão autorizadas a recomendar ou ordenar exames SIDA a pessoas infectadas ou suspeitas de estarem infectadas e uma multa que poderá ir até 100000 yens (cerca de 600 dólares) será aplicada a quem se recusar. Os médicos e funcionários públicos que faltaram ao dever do respeito dos segredos do paciente serão submetidos a uma pena de prisão que pode ir até um ano e a uma multa que pode atingir 300000 yens (cerca de $\$ 2.000$ ). Os estrangeiros infectados com SIDA não serão admitidos no Japão.

Verifica-se o mesmo conflito que noutros paises: por um lado os conselheiros científicos envolvidos no tratamento de doentes com SIDA desejam preservar a privacidade dos pacientes e por outro lado os funcionários governamentais e politicos fazendo pressão para a imposição de medidas draconianas que detenham o alastramento da epidemia.

$\mathrm{O}$ primeiro projecto-lei previa ainda que as pessoas infectadas com o SIDA que se arriscam em actos perigosos tais como dar sangue ou ter relaçðes sexuais seriam punidos com uma multa podendo ir até 300000 yens ( -2000 dólares) ou com uma pena de prisão de 1 ano no máximo. Também os médicos que não tiverem notificado os portadores de SIDA às autoridades sanitárias seriam submetidos a uma pena similar, mas os protestos denunciando estas medidas como infringindo os direitos humanos levaram o Ministério a suprimir estas cláusulas do projecto final.

Hoei Ohama presidente do subcomité recentemente formado do Partido Democrático Liberal para se ocu- par do SIDA, declarou aos jornalistas que é mais importante prevenir o alastramento da epidemia do que proteger a privacidade de grupos de alto risco e "se protegermos os direitos humanos de uma pessoa estaremos a privar outras do direito à vida". Alguns funcionários do Ministério da Justiça sugeriram até que pessoas infectadas com o vírus e que conscientemente o passarem a outras deveriam ser inculpadas de morte no quadro da lei criminal existente.

A lei diz que protegerá a privacidade dos pacientes com SIDA enquanto seguiram os conselhos do médico, mas não é claro como é que os infectados secundários serão seguidos, protegendo-se ao mesmo tempo a sua vida privada. A lei é também muito vaga no que diz respeito à maneira de aplicar as medidas contra os estrangeiros. A Convenção Nacional dos Hemofílicos condenou a lei acusando-a de desumana.

No âmbito de uma campanha pública o Ministério da Saúde distribuiu uma brochura de 100 páginas sobre o SIDA nas municipalidades do país. O Ministério da Educação deu instruçð̃es aos conselhos educativos para iniciarem a educação sobre o SIDA a partir da escola primária. A cobertura dada pela televisâo é actualmente extensiva. Tatsuo Ozawa, anterior Ministro da Saúde, propôs a creiação de uma fundação privada para produzir filmes e vídeos e para manter um serviço telefónico gratuito de informaçðes sobre a doença. No entanto só uma quantia ridícula de 7 milhðes de yens (45 000 dólares) será atribuída à informação pública e a custos administrativos. Uma verba insignificante (comparada com a equivalente de outros países desenvolvidos) de 155 milhð̃es de yens (1 milhão de dólares) será destinada à invesrigação ao longo do ano de 1987. Uma parte destes fundos será destinada à investigação ao longo do ano de 1987. Uma parte destes fundos será utilizada no desenvolvimento de medicamentos para combater a doença, incluindo o recurso à medicina herbática chinesa.

$\mathrm{Na}$ IHolanda uma campanha publicitária intensiva, sobretudo em dois canais da televisão, aconselha a fazer amor nas regras de segurança para deter o SIDA. A campanha informativa explica como se apanha o SIDA, e como se proteger para o evitar e como utilizar os preservativos.

No continente asiático são oficialmente conhecidos casos de SIDA na Índia e na Tailândia. A Índia, com 104 casos detectados em 3000 exames efectuados em grupos de alto risco, começou a tomar as primeiras medidas legislativas no sentido repressivo. Destes 104 casos identificados, 11 eram estudantes estrangeiros, 11 eram turistas, 76 eram protistutas e 6 eram indianos de sexo masculino. A maior parte das prostitutas declarou ter tido relaçðes sexuais com padres estrangeiros que participam em convençðes cristãs. "Com a descoberta do SIDA entre os padres da Igreja Catblica Romana, o papel deles na transmissão da epidemia não pode ser monosprezado" declararam as autoridades indianas. Dada a grande percentagem de infecção entre as prostitutas, foi dada prioridade aos testes obrigatórios deste grupo de alto risco. Mas, depois de, em Calcutá, a policia ter encarcerado uma suspeita, todas as prostitutas da Índia se tem recusado a submeter o seu sangue para análise. Ora estes exames não são obrigatórios porque a prostituição é ilegal. Existe uma proposta para legalizar a prostituição e fazer da obrigação do teste SIDA uma condição para obter a licença para exercer a prostituição.

Por outro lado como $80 \%$ dos 3000 estudantes estran- 
geiros são de origem africana, todo o estudante estrangeiro será obrigatoriamente submetido a testes obrigatórios e os que se recusarem serão impedidos de se apresentarem aos exames. Os casos seropositivos serão expulsos. As associaçðes de estudantes consideram a medida discriminatória e racista. O medo, o ostracismo social, o trauma psicologico decorrente da estigmatização de ser portador do vírus do SIDA comprometem a carreira educacional dos africanos, alegam os dirigentes estudantis.

Também na Bélgica os estudantes estrangeiros à chegada ao país devem ser obrigatoriamente examinados a fim de rejeitar os seropositivos.

Ao nível internacional a OMS considera o SIDA uma das suas prioridades principais. Esta organização avalia que haverá entre 500000 e 3000000 de casos de SIDA em 1991 e cerca de 100000000 de pessoas infectadas com o vírus. Estes números serão certamente subestimados se a epidemia alastrar rapidamente na Ásia e na América do Sul. 100 países necessitarão de assistência técnica para iniciarem e aplicarem os seus programas de prevenção e de controle. Estes programas deverão incluir um estudo para apurar o modo de transmissão do vírus e campanhas de educação pública. Uma pesquisa no âmbito das Ciências Sociais deverá estudar os meios educacionais que levem à utilização generalizada de preservativos e de seringas hipodérmicas esterilizadas descartáveis. Um importante projecto da OMS será o exame global das tendências das legislaçōes sobre o SIDA. A maior parte das legislaçðes estão concentradas na América do Norte, Austrália e Europa se bem que a doença esteja mais desenvolvida na África. Tem havido pressōes sobre a OMS pela parte dos Estados membros para que o SIDA seja considerado como uma crise geral e para que a questão do combate à epidemia seja centralizada mantendo-se no entanto a autonomia de cada país.

\section{A evolução da doença}

Se bem que o número de anos passados em relação à detecção da doença não seja suficiente para estabelecer uma previsão perfeitamente rigorosa da probabilidade que uma pessoa infectada num dado momento venha a desenvolver a doença no decurso de um determinado intervalo de tempo, é possível, com base na evolução dos casos conhecidos de infecção por transfusão sanguínea nos E.U.A. desde 1978 até hoje, fazer um cálculo extrapolativo.

As conclusøes, segundo as avaliações mais recentes, sugerem que o tempo médio de incubação (o tempo decorrido entre o momento em que a infecção se deu, isto é em que o vírus se instalou nas células hospedeiras, até à manifestação da doença) é de 15 anos.

A incidência da epidemia também pode ser calculada com base nos dados anteriores e no reconhecimento dos casos que se vêm declarando anualmente nos E.U.A. e na Grã-Bretanha. A evolução do número de infecçðes deduzida destes cálculos leva a estimativas da ordem dos 2500000 infectados nos E.U.A. em 1984 e de 110000 na Grã-Bretanha em 1985.

A propagação está a ultrapassar todas as espectativas e só poderá aumentar ainda mais ao atingir a Ásia e a América do Sul.

\section{Perspectivas sobre a descoberta de uma vacina}

A palavra vacinação designa na linguagem corrente a prevenção contra uma doença infecciona. Do ponto de vista prático uma vacina contra uma doença (por exemplo a poliomielite, o tétano, a variola) é uma substância (no sentido lato) que depois de introduzida no organismo lhe permite preparar um mecanismo de defesa contra o agente patogénico (bactérias, vírus, toxinas) e capaz de o neutralizar se ele penetrar mais tarde no organismo vacinado. Por outras palavras, a vacinação põe em estado de alerta certos componentes específicos do sistema de defesa imunitária.

A vacinação existia no Ocidente antes de Pasteur. E. Tenner, médico britânico, tinha codificado já no século XVIII a utilização da inoculação duma doença benigna da vaca a vacina, para proteger os humanos contra uma doença muito próxima mas terrível, a variola. Este exemplo deu assim o seu nome à prática: a vacinação. Fornecia igualmente um conceito novo, o de que uma doença atenuada seja capaz de criar um estado de resistência a uma doença mais grave.

Isto define o conteúdo da vacinação: dispor de um agente patogénico atenuado e ter o tempo necessário para que o organismo aprenda a resistir-lhe.

Para compreender os problemas inerentes ao desenvolvimento de uma vacina contra o SIDA é necessário relembrar de maneira forçosamente muito sucinta o mecanismo básico de defesa imunitária do organismo contra um organismo ou uma substância estranha. $\mathcal{O}$ sistema imunitário é comparável ao sistema nervoso. Ambos os sistemas são constituídos por órgãos difusos, dispersos por todos os tecidos do corpo. O sistema imunitário humano é composto de cerca de 1 trilhão $\left(10^{12}\right)$ de células chamadas linfócitos e de 100 quintriliðes $\left(10^{20}\right)$ de moléculas chamadas anticorpos que são produzidos e segregados pelos linfocitos.

As células e as moléculas do sistema imunitário atingem a quase totalidade dos tecidos através do fluxo sanguíneo, entrando nos tecidos através da penetração das paredes dos capilares sanguineos. Os linfocitos encontram-se em grande concentração nos gânglios linfáticos e nos sítios onde são fabricados e processados: na medula óssea, no timo e no baço.

O papel do sistema imunitário é patrulhar o corpo e conservar a sua identidade. Ele é capaz de reconhecer qualquer forma que lhe seja estranha, de origem externa (como por exemplo uma bactéria ou um vírus) ou interna (como por exemplo uma célula cancerosa). Uma vez reconhecido como estranho, o intruso é destruido e eliminado na maioria dos casos, processo que se desenrola incessantemente no nosso organismo.

$\mathrm{O}$ que é reconhecido e combatido pelo sistema imunitário são, em geral, regiðes à superfície de grandes moléculas tais como proteínas, polisacáridos ou ácidos nucleicos, e podem também ser pequenas moléculas orgânicas. As moléculas que exibem estas regiðes com estruturas particulares (chamadas epitopos) reconhecidas pelo sistema imunitário têm o nome geral de antigénio. As proteinas são macromoléculas nas quais se podem incluir enzimas, hormosas, moleculas de transporte tais como a hemoglobina e uma grande variedade de moléculas incorporadas nas membranas celulares ou bacterianas ou que formam a cápsula de envelope dos vírus. Cada epítopo estrangeiro, que não esteja presente em moléculas próprias ao organismo são, é atacado por um anticorpo dirigido particularmente contra ele à semelhança de uma chave à qual só corresponde uma fechadura particular. À variedade quase infinita de epitopos possíveis estranhos ao organismo corresponde uma infinidade de anticorpos que o sistema imunitário tem a potencialidade de produzir. 
Não cabe no âmbito deste artigo detalhar os mecanismos complexos pelos quais o sistema imunitário adquiriu as capacidades extraordinárias de aprendizagem que lhe permitem distinguir o que lhe é próprio, particular ao seu ser (e que está na origem do fenómeno de rejeição dos órgãos transplantados e cujo combate consiste justamente o sistema imunitário) do que lhe é estranho e da produção dum número imenso de anticorpos contra uma infinidade de antigénios possíveis e $a$ priori imprevisiveis. É importante no entanto sublinhar que tudo é antigénico (isto é induz uma imunitária) excepto o que é próprio ao organismo. O sistema imunitário pode sintetizar até 100 milhōes de moléculas de anticorpos diferentes e nenhum reconhece as suas próprias proteinas (ou outras moléculas) cujo número é avaliado entre 10 e 100 mil.

Duas outras propriedades importantissimas do ponto de vista prático (pois são a base do princípio da vacinação) e não menos extraordinárias do sistema imunitário são a memória e a adaptação.

A todo o momento existem no organismo células do sistema imunitário (os globulos) capazes de reconhecer qualquer antigénio isto é qualquer corpo estranho. A resposta primária do sistema imunitário consiste em fazer proliferar unicamente as células que reconhecem, que apresentam afinidade por esse novo antigénio que aparecer no organismo com a consequente produção de anticorpos. Um segundo contacto posterior (que pode ser muitos anos mais tarde) desencadeia uma resposta secundária muito mais forte e rápida do que a primeira devido à presença no organismo de um maior número de células defensoras que tinham sido produzidas pela primeira estimulação das células precursoras. Para além desta manifestação de memória existe uma adaptação do sistema imunitário que se manifesta no facto da afinidade dos anticorpos pelo antigénio aumentar astronomicamente na resposta secundária resultado duma selecção competitiva que leva os receptores de maior afinidade a proliferar com maior frequência.

Estes fenómenos são a base da vacinação que consiste em introduzir no organismo um agente patogénico inactivado do ponto de vista da patogenicidade, mas portador dos antigénios responsáveis pela indução duma resposta imunitária primária (técnica sistematicamente desenvolvida por Pasteur e utilizada na maior parte das vacinas ainda hoje) ou então um simples factor antigénico (uma proteína) preparado independentemente do agente patogénico e de que normalmente faz parte (este é um tipo novo de vacina possível de desenvolver graças às técnicas de engenharia genética de que é exemplo a vacina moderna contra a hepatite B e que é mais segura que as vacinas clássicas que comportam um risco, se bem que ínfimo na maior parte dos casos, devido à possibilidade do agente patogénico não estar perfeitamente desactivado).

Dois tipos essenciais de células estão envolvidas na defesa imunitária: os linfócitos B responsáveis pela chamada imunidade humoral e os linfócitos $\mathrm{T}$ agentes da imunidade celular.

Todos os linfócitos derivam de células precursoras nascidas na medula óssea. Cerca de metade, os linfócitos $\mathrm{T}$, passou pelo timo e a outra metade, os $\mathrm{B}$, não passaram. É impossível distinguir estes dois tipos celulares pela forma. Só as células B secretam os anticorpos também chamados imunoglobulinas que circulam no fluxo sanguíneo que reconhecem epítopos e são essencialmente antibacterianos.

As células $\mathrm{T}$ também reconhecem epitopos e possuem também receptores que não são imunoglobulinas e não secretam anticorpos. As células T podem matar outras células tais como as células cancerosas e os tecidos de órgãos transplantados que exibem epitopos de antigénios estrangeiros. As células $\mathrm{T}$ ajudam as células B a serem estimuladas pelos antigénios. Elas constituem a principal barreira antiviral. De facto um vírus no seu processo infeccioso num determinado tipo de célula expressa certos antigénios à superfície da membrana da célula infectada. As células $\mathrm{T}$ têm a propriedade de reconhecer essa proteína estranha antigénica estranha induzida pelo vírus. Elas reconhecem o antigénio viral e o centro produtor do vírus em que se tornou a célula infectada e matam esta célula indesejável, num caso normal e de preferência antes que ela tenha tido tempo de largar, após ter sido ligada, um número maior ou menor de virus que tiveram tempo de se multiplicar no seu interior e que por sua vez irão infectar também outras células, num processo cíclico e repetitivo que acabará com a morte do organismo.

É evidente que um organismo vacinado terá muito maior probabilidade de se defender com sucesso depois dum primeiro contacto não infeccioso artificialmente propiciado para estimular, alertar as defesas imunitárias do organismo como ficou explicado. É também evidente que em caso de haver possibilidade de escolha é sempre preferível a vacina à imunização pela aquisição da doença mesmo benigna que pode sempre deixar sequelas ou que, devido à persistência silenciosa do agente infeccioso, poderá vir a manifestar-se sobre forma diferente anos mais tarde.

$\mathrm{O}$ virus do SIDA (sindroma de imunodificiência adquirida) tem várias características que o tornam particularmente terrivel. As células pelas quais ele tem afinidade, que são alvo do seu ataque, são precisamente as células $\mathrm{T}$ responsáveis pela imunidade celular (daí o seu nome IHIV - human immunodeficiency virus). Após penetração permanece por um período que pode ir para além de 5 anos sem manifestação aparente e sem que as células infectadas, por razôes desconhecidas, sejam destruidas por células $\mathrm{T}$ sãs. Além disso existem actualmente dois tipos principais conhecidos do virus do SIDA o IHIV-1 e o IHIV-2 aos quais correspondem vários subtipos. O que distingue praticamente cada um destes subtipos é que eles expressam antigénios diferentes. Uma vacina eficaz terá forçosamente de comportar todos os antigénios indutores possíveis da resposta imunitária primária. Portanto a descoberta da diversidade de subtipos do vírus IIIV torna-nos imediatamente conscientes das dificuldades que a descoberta de uma vacina levanta porque a resposta humoral induzida por um subtipo de vírus gera a formação de anticorpos neutralizantes específicos desse subtipo e não forçosamente dos outros subtipos.

Por outro lado, como deverá parecer claro em função da introdução explicativa anterior, uma vacina eficaz só pode ser uma vacina que active uma resposta imunitária baseada num sinal de reconhecimento que active tanto as células $\mathrm{T}$ citotóbicas como as células B que secretam os anticorpos e que são dependentes das células T. Por outras palavras, as células infectadas passam por um estado imunogénico em que os antigénios virais estão presentes na membrana celular antes que elas libertem o vírus. A activação de uma resposta imunitária mediada por células deveria portanto suprimir a disseminação viral tanto pela destruição destas células pelas células específicas $\mathrm{T}$ citotóbicas, como pela neu- 
tralização do vírus livre mediada pelos anticorpos circulantes.

Vários sistemas de vacinas têm sido estudados em vários laboratórios de diferentes países utilizando para a experimentação o primata mais próximo do homem, o chimpazé. Não existe número suficiente de chimpazés para todos os testes necessários e tem sido sugerido que se comece a inoculação de vacinas experimentais em voluntários humanos. Assim os primeiros testes em humanos foram realizados no Zaire com o acordo do governo mas sem o consentimento oficial da OMS. Esta primeira vacina experimental foi desenvolvida pelo Dr. Z. Lurhuma director do laboratório de imunologia da Clínica Universitária de Kinshasa, pelo general J.J. Salum chefe do Instituto Nacional de Investigação Biomédica de Kinshasa (primeiramente Instituto Pasteur e agora operando com a ajuda e a cooperação francesa) e pelo Dr. Daniel Zagury da Universidade Pierre e Marie Curie.

A pesquisa de Zagury em parte levada a cabo com a cooperação do Dr. Roberto Gallo conduziu à preparação de uma vacina estudada para impedir a proppagação viral estimulando as células T do sistema imunitário para destruirem as células infectadas pelo vírus do SIDA e portadores da proteina do envelope viral na sua superficie. Esta destruição é mediada não só pelas células do sistema imunitário mas também por anticorpos neutralizantes do vírus. O protótipo da vacina tem que possuir por isso uma base diferente de várias outras candidatas baseadas na proteina de envelope purificada que estimula sobretudo a imunidade humoral estó é a produção de anticorpos.

Para induzir uma resposta imunitária completa em indivíduos seronegativos HIV, imunologicamente normais, os pesquisadores usaram um vírus recombinante IIIV-vacina - um vírus que é preparado pelas técnicas da engenharia genética moderna inserindo no material genético do virus da vacina (que serve como vimos mais acima de vacina para a imunização contra a varíola) genes do virus HIV do SIDA - que produz antigénios importantes no reconhecimento pelo sistema imunitário, tais como a proteina principal de envelope. Esta técnica de recombinação do vírus não patogénico da vacina com material genético dum vírus patogénico contra o qual se deseja obter a imunização já foi utilizada na preparação de vacinas contra o vírus da hepatite B, da gripe e da raiva. Experimentaçðes sobre animais seguidas de outras sobre voluntários humanos entre os quais o próprio investigador Dr. Daniel Zagury mostraram a ausência de efeitos tóxicos e uma resposta imune do tipo celular e humoral foi posta em evidência. Como resultado destas primeiras experiências a vacina está a ser experimentada a escala reduzida em voluntários de alto risco no Zaire.

Um problema importante é como já vimos a existência de vários subtipos de IHIV e será preciso preparar vírus recombinantes múltiplos cada um expressando um subtipo diferente de antigénio específico. Antes de partir para uma vacinação em larga escala há pois que ultrapassar as limitaçðes impostas pela diversidade dos subtipos. E mesmo depois deste objectivo ser atingido, o que pode levar um número de anos difícil de prever, só a prática poderá mostrar até que ponto cada um dos diferentes tipos de vacinas actualmente em desenvolvimento será eficaz no combate à epidemia viral causa do SIDA.

\section{Tratamento}

O desenvolvimento de um agente antiviral deve ter como objectivo atingir uma das fases críticas própria do ciclo de vida do IIIV. Uma fase particular a esta classe de virus dita retrovírus é a replicação, fase em que $o$ virus se multiplica por um mecanismo bem diferenciado dos mecanismos próprios às células $\mathrm{e}$ aos outros tipos de vírus. A particularidade deste mecanismo põe em jogo uma enzima exclusiva aos retrovírus chamada transcriptase reversa. Um medicamento que atingisse esta enzima de maneira selectiva sem intoxicar outros constituintes essenciais das células poderia ser eficaz.

Acaba de ser comercializado um medicamento que, pelo menos parcialmente, atinge este objectivo que é a 3-azido-3-desoxitimidina ou AZT, comercializado com o nome de Retrovir pela firma americana Burroughs Wellcome. Esta substância análoga duma substância natural (a timidina) utilizada pela transcriptase reversa, tem a propriedade de enganar a enzima e de bloquear a sua função. A síntese química desta substância é relativamente complexa e a quantidade produzida não satisfaz sequer a demanda nos E.U.A.

A Wellcome espera ter uma quantidade suficiente para responder às necessidades sobretudo de pacientes seriamente atingidos com Pneumocytis carinii (que é um dos sintonas próprios do SIDA mais frequentes nos doentes americanos e europeus), grupo que tem respondido bem ao tratamento.

A utilização do medicamento foi já autorizada nos E.U.A. e em vários paises europeus, mas a produção ainda insuficiente limita a sua utilização unicamente aos pacientes em fase terminal da doença com menos de 200 linfócitos $\mathrm{T}$, ou atingidos de pneumonia.

Se bem que não cure o SIDA, o AZT aumenta a sobrevivência a curto termo. A facilidade e a rapidez com que o medicamento foi aprovado denotam o desespero de causa e a urgência que é necessária para combater uma epidemia em progressão constante.

Os pacientes tratados pelo medicamento representam uma fracção infima do total dos indivíduos atingidos com SIDA. Estão ainda a ser estudados os efeitos do AZT em pacientes atingidos do Sarcoma de Kaposi (outros dos sintomas principais) em crianças doentes do SIDA e em seropositivos infectados com o vírus mas em que não se manifestam problemas neurologicos tais como perda de memória, diminuição das suas capacidades intelectuais, depressão e demência. Alguns doentes pertencentes a este último grupo recuperaram algumas das faculdades mentais perdidas. Foram observados efeitos secundários tais como anemia severa. A supressão da medula óssea, fonte das células responsáveis pela defesa imunitária do organismo, deixa os pacientes tratados com o medicamento vulneráveis às infecçð̃es bacterianas. A toxicidade do Retrovir obriga a uma certa percentagem de doentes a terem de abandonar o tratamento e os efeitos a longo prazo são desconhecidos.

Uma outra fase do ciclo de vida do vírus que poderia ser particularmente vulnerável é a da interacção do vírus com as células $\mathrm{T}$ alvo da infecção. Esta interacção é condicionada por um tropismo que leva proteinas do envelope viral a interagir fortemente com proteinas da membrana que circunda as células $T$. Estas proteinas do envelope viral ou da membrana celular poderiam ser vulneráveis ao ataque por certas substâncias químicas ou por peptídeos (pequenos fragmentos de proteí- 
nas que podem ser sintetizados artificialmente). A estrutura destas proteinas começa a ser conhecida em pormenor e o seu bloquei poderia levar à ruptura da sua interacção e impedir a infecção.

Um medicamento com características pelo menos próximas das indicadas está a ser utilizado a título experimental na Suécia. O medicamento tem o nome de peptídeo $\mathrm{T}$ e foi preparado por um grupo de investigadores suecos do Instituto Karolinska dirigido por Lennart Wetterberg. Esta equipa especializada no estudo de receptores peptídicos cerebrais, decidiu investigar se os pacientes com SIDA apresentando os problemas neurológicos citados acima possuiam células cerebrais infectadas pelo vírus.

Descobriram que no cérebro existem receptores neuropeptidicos que reconhecem a proteína $\mathrm{T} 4$ das células $\mathrm{T}$. Um neuropéptido que ocorre naturalmente reage com o marcador da célula $\mathrm{T}$ que é o receptor do vírus do SIDA. Este neuropéptido poderia impedir a ligação do vírus à membrana das células que ele infecta bloqueando a região de interacção. Este neuropéptido cerebral deve possuir uma estrutura muito próxima ou idêntica à região da proteina do invólucro viral que reconhece a mesma região da membrana da célula T4. A pesquisa por computador de regiðes estruturalmente idênticas entre peptídos conhecidos e a proteína do invólucro viral de estrutura também conhecida levou à descoberta do peptído T. Este peptído impede a replicação e multiplicação do vírus provavelmente impedindo-o de entrar nas células. Aparentemente não tem efeitos tóxicos e quando foi administrado a pacientes no estado terminal da doença o número de linfócitos aumentou de maneira significativa e os efeitos do virus no seu cérebro diminuiu fortemente.

Mas o péptido T não mata o vírus $\mathrm{HIV}$ e os pacientes podem de novo sofrer infecção dos seus linfócitos assim que o péptido deixa de ser administrado. No entanto, administrado ao mesmo tempo que outros medicamentos tais como o AZT descrito mais acima, poderá surtir o sucesso desejado na cura do SIDA. É no entanto demasiado cedo para especular, se bem que os primeiros resultados sejam prometedores.

\section{Considerações finais}

Dois pontos de vista extremos têm sido defendidos nos E.U.A. e na Europa. Segundo um deles o SIDA surgiu porque alguns grupos sociais marginais têm práticas sexuais contra-natura ou injectam drogas no sangue e o SIDA desaparecia se estas práticas fossem proscritas conseguindo proteger-se por este meio a sociedade contra a doença.

A outra opinião considera que a epidemia se tem propagado tão rapidamente desde que foi admitida como uma doença particular em 1981 e continua a propagar-se a um ritmo tal que receia ser só uma questão de tempo para que uma parte substancial da população mundial sucumba numa proporção comparável à que resultará de uma guerra nuclear mundial.

Já vimos a que ponto a primeira teoria é falsa e simplista em particular através das características da infecçâo em África (e igualmente nas Caraíbas) onde a mesma proporçâo de indivíduos normais dos dois sexos é portadora do vírus, sendo a noção de população de risco, muito diferente da actualmente considerada nos E.U.A. e noutros continentes.

Quanto à segunda, deve-se dizer que é descabido e impossivel fazer prognósticos a longo tempo. O que não invalida a necessidade urgente de tomar medidas severas que detenham a propagação da epidemia.

É evidente que a educação do público deve ser a primeira linha de defesa. A maior dificuldade será a de tentar mudar os hábitos sexuais das pessoas só pela exortação. Os grupos sociais mais vulneráveis e mais activos na propagação da infecção (a começar pela juventude) serão insensiveis à persuasão. É absolutamente necessário introduzir uma educação sexual implícita nas escolas públicas substituindo eufemismos tais como contactos íntimos por explicaçðes concretas nos termos mais vernáculos. Há pois que ultrapassar a dificuldade perturbadora socialmente e introduzir a expliciticidade necessária.

Nos E.U.A. o Serviço Público de Saúde e o Departamento de Educação entraram em conflito a este respeito e na Europa Ocidental há que contar com a reacção dos que professam a castidade como conduta de vida e que consideram mais fácil doutrinar as inocentes crianças sobre as virtudes da família nuclear que esclarecê- las acerca da eficácia dos preservativos como meio de detenção de infecçōes venéreas. A não ser que se imponham cintos de castidade a todas as crianças, só uma educação sexual explícita da juventude oferece esperanças de evitar uma catástrofe possível.

No que diz respeito à transmissão da infecção através de seringas hipodérmicas usadas e contaminadas para administração de drogas intravenosas, o combate à droga e a prática de venda de seringas esterilizadas descartáveis à venda em farmácias, como a adoptada na França, parece contraditoria. Mas que outro meio existe para deter este reservatório de infecçð̃es que é o grupo dos toxicómanos de drogas administradas por via intravenosa sabendo que estes têm sido impossiveis de localizar e de eliminar apesar dos gigantescos meios de combate à droga até hoje mobilizados?

A proposta derrotada em Novembro passado na California que exigia que a condição dos doentes infectados com o SIDA fosse registada publicamente, tem defensores acérrimos na RFA e foi adoptada na Suécia. Esta medida é defendida com a argumentação de que se a sociedade está realmente ameaçada, os individuos que transmitem a doença deveriam ser identificados e evitados, e como consequência votados ao ostracismo geral como nas antigas colonias de leprosos. Na realidade haveria poucas probabilidades que parceiros sexuais solicitados por uma emergência sexual fossem exigentes a ponto de consultar os registos públicos que serão sem dúvida utilizados para outros fins nem sempre realmente benignos. $O$ argumento de que trazer consigo um cartão individual provando que a pessoa foi submetida ao teste diagnóstico do SIDA permitiria que se evitassem parceiros perigosos é amplamente desmentido pelos factos. De facto o único diagnóstico largamente aplicado pelo momento é baseado na detecção da presença de anticorpos antivírus. Ora eles aparecem em geral só vários meses, por vezes um ano (talvez mais), após a infecção.

Isto significa que, por mais rigoroso que fosse o controle, seria impossivel de identificar todos os portadores do vírus. Seguir o rasto das pessoas infectadas a fim de diagnosticar qualquer infeccioso potencial? Uma política compulsória neste sentido está antecipadamente votada ao fracasso. Primeiramente as pessoas em risco não estão de maneira nenhuma dispostas a oferecem-se para testes de diagnóstico se souberem que os seus contactos vão ser seguidos. A segunda dificuldade é a de investigar a vida duma pessoa sem man- 
char a reputação de todas as pessoas implicadas. Para além disso seguir todos os contactos sexuais duma pessoa infectada é tarefa dispendiosa em termos de dinheiro e de tempo. É o género de batalha perdida antecipadamente. Qualquer medida compulsória é contraproducente na medida em que corre o risco de fazer deslizar a progressão da epidemia para um nível subterrâneo em que forçosamente se tornará mais perigosa e difícil de controlar.

Uma questão recentemente levantada nos E.U.A. com a qual as autoridades se estão a debater é a de saber se é adequada a tentativa de fazer uma estimativa pormenorizada da incidência da infecção na população a fím de prever o desenvolvimento da epidemia, fazendo testes de diagnóstico anónimos ao sangue de pacientes tirado à partida para um propósito completamente diferente. Os testes anónimos são no entanto proibidos porque violam a pedra angular da ética que explicita que uma pessoa tem que dar o seu consentimento prévio para tudo o que possa ser feito consigo ou com o seu organismo. Outra objecção ética a este procedimento é que os anónimos de que se descobrisse sangue infectado ficariam na ignorância do seu estado.

IHá quem se diga escandalizado pela linguagem necessária para chamar as coisas pelo seu nome na luta pela prevenção pretendendo que há demasiado pânico. As verbas gigantescas consagradas à educação pública justificam-se plenamente pela possibilidade real de o SIDA ser uma ameaça para a sobrevivência de populaçð̄es inteiras. Os E.U.A. estão a servir de exemplo pela dimensão da epidemia no seu território e da luta para a combater. O Congresso americano está confrontado com um pedido de verba de 2 biliōes de dólares por ano para a salvação da humanidade, soma inferior à reclamada pela Strategie Defense Iniciative (SDI) exactamente para a mesma finalidade.

Se o SDI desaparecesse o mundo talvez não se tornasse mais perigoso (talvez fosse mesmo mais seguro) mas se a luta profilática contra o SIDA falhar nós estaremos provavelmente a caminho de uma calamidade.

A investigação é um processo infindável que não pode dizer-se como irá evoluir. 0 imprevisível faz parte da própria natureza da construção científica. Se aquilo que se vai encontrar é realmente novo, então é por definição algo previamente desconhecido. Não há processo nenhum de dizer onde irá conduzir um dado domínio de investigação. É por isso que não é possível escolher determinados aspectos da ciência e rejeitar outros.

François Jacob

in "O Jogo dos Possíveis"

$/ 1$

A dificuldade em ver aprovados projectos de investigação é universal (embora o grau de dificuldade seja uma função, possivelmente local, de várias variáveis). No Reino Unido circula a seguinte anedota:

"Como as restrições orçamentais atingissem todos sem excepção, até Deus se viu forçado a submeter um projecto. O parecer da comissão competente não se fez esperar: o projecto era liminarmente rejeitado, atendendo ao duvidoso curriculum científico do proponente. A negação fundamentava-se em três pontos: (i) $O$ cientista em questão tem uma única publicação. (ii) Essa obra não é recente. (iii) Falharam até hoje todas as tentativas de reproduzir as experiências descritas na publicação". 